\title{
CALVYN EN DIE SKRIFGESAG
}

Prof. dr. L. F. Schulze

\section{INLEIDING}

Die probleem van die Skrifgesag het die (teologiese) geeste nog altyd in beroering - vandag (ná die Aufklärung!) nog meer as gedurende die sestiende eeu. Gedurende die laaste paar jaar is ons in Suid-Afrika hardhandig uit ons isolement geruk en skielik lewensgroot gekonfronteer met die probleem van die Skrifgesag. Ek verwys hier na W. S. Vorster se inougurele rede by Unisa (1977) oor die N.T. as 'n ou boek in 'n moderne wêreld. Vervolgens na die verskyning van 'n bundel opstelle onder die titel Scripture and the Use of Scripture, waarvan Vorster redakteur was (1979). Daarin kry ons dit in die eerste artikel, van J. A. Loader, al dik op die brood gesmeer:

"The fact of biblical authority is, however, unproblematically accepted and implied throughout the conventional South African literature. In addition it should be said that the problem of biblical authority is never (as far as I can see) analysed as a problem of ancient/modern, but rather related to the opposition divine/human. I would have thought that this is a very important perspective that was raised last year by $W$. S. Vorster in his controversial inaugural lecture at Unisa (1977) on the New Testament as an old book in a modern world (stirring up quite agitated flurries of reaction in the process). The question of elbow-room for the so-called human factor in the Bible has further lost its cutting edge because only fundamentalist opinion does not accept that the Bible is a human book with "errors" 1.

Gesien tcen hierdie agtergrond, is dit seker nie onvanpas om weer 'n keer na Calvyn se opvatting van die Skrifgesag te kyk nie. Immers, met die voorbehoud dat belydenis en teologie onderskei moet word ${ }^{2}$, kan ons tog sê dat die opvattinge van die Hervormers en veral van Calvyn, die agtergrond vorm van ons belydenisskrifte.

Die opset is dan om enkele fasette van Calvyn se Skrifbeskouing uit te lig, nie om iets nuuts hieroor te sê nie, maar om dit aan ons en ons tyd as 'n spieël voor te hou.

\section{CALVYN SE EERBIED VIR DIE SKRIF}

Seker die eerste ding wat 'n mens by Calvyn opval, is sy diepe eerbied vir die Woord van God. Dit is ook goed te verstaan as 'n mens daaraan dink dat die Reformasie in 'n sekere sin weer die Skrif ,nuut" ontdek het, weer die viva vox Dei, die lewende stem van God in die Bybel gehoor het. Reeds in die konfessie van 1537 staan die belydenis van die Skrif as Woord van God voorop. Vry vertaal lui Art. 1: Ten eerste bevestig ons plegtig dat ons die enige Skrif vir die reël van ons geloof en godsdiens wil volg, sonder om daarby enige saak te vermeng wat deur die mense versin is buite die Woord van God om ${ }^{3}$. Dat hierdie uitspraak 
werklik belydenis wil wees en nie 'n blote formele prinsipe is nie, word duidelik gemaak deur ander uitsprake van Calvyn. Reeds in die voorwoord van die Institusie word die Skrif aangedui as 'n hemelse uitspraak wat nie kan lieg nie ${ }^{4}$. Die Skrifte is die enigste bron waarin dit God behaag het om sy waarheid vas te lê tot 'n ewige herinnering ${ }^{5}$. Verlig deur die Heilige Gees het ons geen redelike argumente nodig nie, maar voel ons ten volle oortuig dat die Skrif, deur bemiddeling van mense, vanuit God se eie mond na ons gekom het ${ }^{8}$. Saam met Augustinus kan Calvyn die Skrif tipeer as ,die skatkamer van die Here" ". Teenoor die RoomsKatolieke verering van die sakrament (nagmaal) stel hy dat ons ons oë, ore, harte, gedagtes en tonge ten volle moet rig op die op die heilige leer van God. Die Skrif is immers die skool van die Heilige Gees, die beste van alle leermeesters ${ }^{8}$. In 'n preek oor Deut. 4 sê hy: Die eerste punt van die Christendom is dit: dat die Heilige Skrif ons hele wysheid is en dat ons God, wat daarin spreek, moet hoor, sonder om iets daaraan toe te voeg ${ }^{\circ}$. De Groot teken Calvyn se eerbied treffend, wanneer hy verwys na Inst. 1, 7, 4. Hy sê:

,Ja, zulk een diepen indruk heeft Calvyn van den goddelijken glans, die over de Schrift verspreid ligt, dat hij er niet aan twijfelt, of zelfs door ongeloovigen, zou, indien ze niet door een geweldige onbeschaamdheid waren verhard, deze bekentenis worden afgedwongen, dat er in haar woorden en duidelijke teekenen worden gevonden, dat God in haar spreekt en dat de leer, die ze brengt, hemelsch is" 10 .

Een van die treffendste voorbeelde van Calvyn se diepe eerbied vir die Skrif tref ons aan in sy drie-en-dertigste preek oor Deuteronomium. Daarin skerp hy die gemeente ook op tot dieselfde eerbied. Daar betoog Calvyn dat ons moet begryp dat God bo alles die eer en die gesag van sy Woord by ons aanbeveel. S6 asof Hy sê dat alles wat in die Heilige Skrif vervat is, deur ons in alle nederigheid ontvang moet word en ons dit moet gehoorsaam. En alhoewel dit teen ons sin sou wees en ons sou wens dat God volgens ons smaak (letterlik manier) gepraat het, tog moet ons Hom hierdie eer toebring om ons sinne gevange te neem en te sê: Here, ons is u dissipels: ons ontvang rustig dit wat $U$ behaag het om ons te leer, want ons weet dat dit tot ons voordeel en saligheid is. Sonder uitsondering dus: laat alles wat in die Heilige Skrif vervat is, ontvang word met eerbied.... ${ }^{11}$.

Hieruit is dit duidelik dat hy wat die Skrif nie gehoorsaam nie, God nie eer nie. Hy wat die Skrif minag, minag eintlik God self. Daarom dat Calvyn hom so skerp uitlaat teen die mense wat hulle op die ,inwendige lig" beroep en die Skrif in wese links laat lê. Sulke mense, sê hy, moet nie juis beskou word as onder die invloed van dwaling nie, maar wel van malheid. Die Heilige Gees wil immers dat ons Hom sal herken in die beeld wat Hy op die Skrifte afgedruk het ${ }^{12}$.

Dit is duidelik dat ons hier ver verwyder is van die laatskolastiek, waar die Skrifgesag 'n formele prinsipe geword het. Vir Calxyn gaan dit om die lewende relasie van God en mens. In en 
deur die Skrif kan God geken word, want sy beeld is op die Skrif afgedruk. Eerbiedige ontvangs van wat God sê, nederige luister na sy Woord, geleer word deur die hemelse Leermeester - só eer ons God en word ons wys to saligheid.

\section{DIE ONTSTAAN VAN DIE SKRIF}

(a) Alhoewel Calvyn sê dat ons in die Skrif die stem van God self hoor, beteken dit nog nie dat hy meen dat die Skrif soos die Koran meteens as ' $t$ ware klaar uit die hemel geval het nie. Die Bybel is ook nie Gods Woord in die sin dat dit in sy geheel identies is met die oorspronklike openbaring nie. Inteendeel, Calvyn onderskei baie duidelik tussen die oorspronklike openbaring van God en die optekening daarvan. Laasgenoemde het soms eers baie later gebeur. By gebrek aan 'n volledige Afrikaanse vertaling van die Institusie haal ek hier die vertaling van Beveridge aan.

„The course which God followed towards his Church from the very first, was to supplement these common proofs by addition of his Word, as a surer and more direct means of discovering himself. And there can be no doubt that it was by this help, Adam, Noah, Abraham, and the other patriarchs, attained to that familiar knowledge which, in a manner, distinguished them from unbelievers" 13 .

Hierdie oorspronklike openbaringswoord was ongeskrewe en mondeling aan die nageslag oorgelewer. Dit word duidelik uit paragraaf 2 van die sesde hoofstuk van Boek 1 van die Institusie:

"Whether God revealed himself to the fathers by oracles and visions, or, by the instrumentality and ministry of men, suggested what they were to hand down to posterity, there cannot be a doubt that the certainty of what he taught them was firmly engraven on their hearts, so that they felt assured and knew that the things which they learnt came forth from God, who invariably accompanied his word with a sure testimony, infinnitely superior to mere opinion. At length, in order that, while doctrine was continually enlarged, its truth might subsist in the world during all ages, it was his pleasure that the same oracles which he had deposited with the fathers should be consigned, as it were, to public records" 14 .

Ook van Jesaja, Jeremia, Hosea en die evangeliste sê Calvyn dat hulle eers later hulle geïnspireerde woorde te boek gestel het. (b) Daar is nie net (gewoonlik) 'n tydsverskil tussen die openbaring en die teboekstelling daarvan nie, maar ook 'n kwantiteitsverskil: God het oorspronklik veel meer geopenbaar as wat Hy op Skrif laat stel het. Dit geld nie net vir die optrede van Jesus nie - daarvan getuig die Skrif self dat Hy veel meer gesê en gedoen het (Joh. $21: 25$ ) - maar Calvyn sien dit tot 'n groot mate ook geld vir die Ou Testament. In sy kommentaar op Hosea merk hy by $14: 10$ op dat die profeet, nadat hy eers breedvoerig tot die volk gespreek het, ten slotte die kort inhoud van sy woorde op skrif gestel het. Dit is onwaarskynlik, sê Calvyn, dat Hosea, wat soveel jare as leraar van sy volk opgetree het, slegs só min gesê het as wat hy in drie 
uur kon kwytraak. Dit sou belaglik wees (hoc esset ridiculum!) Maar dit wat hy dikwels moes herhaal, het hy later in 'n paar hoofstukke saamgevat om as 't ware 'n wettige verseëling van die hele leer te wees ${ }^{15}$.

Calvyn het dus nie die Skrif gesien as 'n woordelike weergawe van die openbaring van God nie - dit was eerder 'n kort samevatting daarvan. Met hierdie onderskeiding in gedagte kan ons nou kortliks 'n oorsig gee oor Calvyn se visie op die ontstaan van die Skrif. Die openbaring van God aan die aartsvaders gegee, is later op skrif gestel (vgl. Engelse aanhalings hierbo). Later het die profete gekom om die leer van die (reeds geskrewe) wet vir die volk te ontvou en voorspellings van die toekoms daarby te voeg. Maar omdat dit God behaag het dat die leer in ' $n$ duideliker en omvattender vorm sou bestaan - en dit om die swak gewetes beter te bevredig - het Hy gebied dat ook die profesieë opgeskryf en vir 'n deel van sy Woord gehou sal word. Hierby is die geskiedenisse gevoeg, wat ook die werk van die profete was, maar gedikteer deur die Heilige Gees (Spiritu Sancto dictante). Maar toe eindelik die Wysheid van God in die vlees geopenbaar is, het $\mathrm{Hy}$ aan ons ten volle ontvou alles wat die menslike verstand van die hemelse Vader kan vertsaan of behoort te dink ${ }^{10}$.

Calvyn erken dus 'n geskiedenis van die openbaring en 'n geskiedenis van die teboekstelling van die Skrif.

(c) Alhoewel die optekening van die openbaring gewoonlik eers later plaasgevind het, was dit nie oorgelaat aan die vrome gemoed van die bybelskrywers om na hulle goeddunke dit te doen nie. Ten spyte van J. A. Cramer ${ }^{17}$ se poging kan Calvyn nie vir die etiese standpunt gemonopoliseer word nie. Daarteen pleit die Spiritu Sancto dictante reeds oortuigend. Voeg hierby die tipering van die bybelse skrywers as organe en instrumente van die Gees, mense deur wie se mond hy gespreek het, gewisse en outentieke (geloofwaardige) skrywers en notarisse van die Gees, skrywers of griffiers onder die mond van God. Ons kan hierby nog 'n derde groep uitdrukkinge voeg, dié $\mathrm{nl}$. wat iets verduidelik van die verhouding tussen die "Outeur" en die "skrywers": die Gees het die woorde in hulle mond gelê, die woorde in hulle mond laat invloei, die woorde aan hulle gedikteer ${ }^{18}$. Dit alles spreek duidelik genoeg vir die feit dat Calvyn die ,deurgewers" van die openbaring, beide vir hulle spreke en skrywe, aandui as organe en instrumente, skrywers en griffiers, ens. Die essensie van al hierdie uitdrukkings kom daarop neer dat die Skrif self 'n outentieke, betroubare weergawe van Gods openbaring en wil is, dat die Skrif waaragtig is, dat ons God op sy Woord kan neem.

(d) Ondertussen moet die „dikteer" van die Heilige Gees ons nie verlei om te meen dat Calvyn die meganiese inspirasie geleer het nie. Verskeie tipiese uitdrukkings van die Ortodoksie, bv. dat die skrywers "penne" of "fluite" van die Gees was, ontbreek by hom. Meer nog: hy het 'n oop oog gehad vir die persoonlikheid, gawes, historiese agtergrond en verantwoordelikheid van die bybelskrywers. Calvyn kan in een sin die Gees noem as Outeur van 'n bepaalde boek, terwyl hy in ' $n$ volgende sin dit op rekening van Jesaja of 
Paulus kan sit. Hy kan praat van die „taal en styl van die Heilige Gees", terwyl hy op ander plekke kan wys op die taal- en styleigenaardighede van die verskillende skrywers. So kan hy spreek van Jesaja wat beskuldig, oortuig en verwyt, van Jeremia, Joël en Habakuk wat die gebreke van die Jerusalemse Kerk beween, oor Jakobus wat eis, beveel, vermaan, disputeer, ens. ${ }^{19}$. Hy sê dat die Apostels as skrywers die OT selfstandig aanhaal en daarby nie altyd op dieselfde manier te werk gaan nie ${ }^{20}$, terwyl hy anders weer kan sê dat die Gees deur die mond van Paulus Jesaja uitlê ${ }^{21}$. Daar is verskil van karakter: Matteuis is in die vermelding van 'n saak uitvoeriger as Lukas. Daar is 'n verskil in styl tussen die skrywers: die redevoeringe van o.a. Dawid en Jesaja vloei maklik, terwyl dié van Amos en Sagaria 'n meer eenvoudige indruk maak ${ }^{22}$. Lukas skryf 'n Grieks wat vol Hebreismus is terwyl die brief aan die Hebreërs 'n ander styl het as dié van Paulus en beswaarlik van hom afkomstig kan wees.

Ten slotte kan ons, wat dié afdeling betref, daarop wys dat so min as wat die ,skrywers" mense van dieselfde geaardheid en talente was, so min was die oorspronklike openbaringsorgane dit. Eintlik is die verskil hier nog veel groter: ons het hier aan die een kant Christus, die sondelose Lam, die Wysheid van God, wat die Vader aan ons bekend maak. Aan die ander kant het ons selfs ogelowiges (Bileam, Melgisedek, Pilatus) wat teen hulle sin of buite hulle wete om deur die Gees gebruik word om God se Woord te spreek - al verstaan hulle dit self in sy diepte nie ${ }^{23}$.

Ons het getrag om vanuit verskillende hoeke 'n kort kykie te gee in Calvyn se uiteensetting van die ontstaan van die Skrif. Ons laat hierdie saak, met al sy onduidelikhede en skynbare teenstrydighede, vir 'n oomblik rus om eers dieper te delf in die geheim van die openbaring.

\section{DIE GEHEIM VAN DIE OPENBARING}

Die openbaring is die werk van die Drie-enige God. Calvyn sê dat ons deur die Skrif God leer ken. Tog sê hy ook méér as dit: die geheim, die grond, die bewerkende oorsaak of die bemiddelaar van die openbaring en van die inspirasie is die ewige Seun van God. Calvyn raak liries wanneer hy oor die profetiese amp van ons Here Jesus Christus praat. Ek verwys in dié verband op enkele uitsprake in sy kommentaar op die Evangelie van Johannes en haal 'n gedeelte van 'n paragraaf uit die Institusie aan.

Wanneer Johannes die Seun as die Logos aandui, gebeur dit, sê Calvyn, ten eerste „omdat Hy die ewige Wysheid en Wil van God is en vervolgens die uitgedrukte beeld van sy raad is" ${ }^{24}$. Hy is die enige en ewige Bron van Lig, dit lê in sy wese en eie-aard om te verlig. Reeds in Joh. $1: 18 \mathrm{kom}$ die Seun as die geheim van die openbaring, wat ons die Vader verklaar het, in die gesig. Van die Eniggeborene word gesê dat $\mathrm{Hy}$ uit die skoot van die Vader is om daarmee te kene te gee, sê Calvyn, dat die Seun in die mees verborge geheime van die Vader ingewy is, sodat ons kan weet dat ons in die evangelie as 't ware die ontblote hart van God het ${ }^{25}$. In Hom is alle skatte van kennis en wysheid en alles wat 
die Vader gedink of bepaal het, is aan die Seun van ewigheid af bekend. In die woorde van De Groot:

„De Zoon Gods is de mogelijksgrond van alle openbaring. Hij is de Bron waaruit de openbaring wordt geput. Daar zou nooit eenige openbaring geweest zijn, indien $\mathrm{Hij}$ niet altijd een volkomend adaequate kennis had bezeten van het Wezen en de geheimen de Vader en niet genegen was om van de kennis aan de menschen mede te deelen. Daarom moet ook alle inspiratie, die in den dienst der openbaring zulk een cardinale rol speelt tot Hem als haar laaste en eeuwige oorsprong worden herleid" ${ }^{26}$.

Christus is nie net die geheim van die openbaring nie, maar ook sy hoogtepunt en sentrum. In Christus, die lewende beeld van God, het ons die volkomenheid van die openbaring bereik want deur Hom het God tot ons soos met sy eie mond gespreek.

Pragtig sê Calvyn ook hierdie dinge in die Institusie:

„For how would they have comprehend the mysteries of God in their mind, or declared them to others, unless by the teaching of him, to whom alone the secrets of the Father are known? The only way therefore, by which in ancient times holy men knew God, was by beholding him in the Son as in a mirror. When I say this, I mean that God never manifested himself to men by any other means than by his Son, that is, his own only wisdom, light and truth. From this fountain Adam, Noah, Abraham, Isaal, Jacob, and others, drew all the heavenly doctrine which they possessed ${ }^{27}$.

„But when at length the Wisdom of God was manifested in the flesh, he fully unfolded to us all that the human mind can comprehend, or ought to think of the heavenly Father. Now, therefore, since Christ, the Sun of Righteousness, has arisen, we have the perfect refulgence of divine truth, like the brightness of noon-day, whereas the light was previously dim" ${ }^{28}$.

\section{DIE OUTEUR VAN DIE SKRIF}

Terwyl Christus die geheim en Bron van alle openbaring is, verbaas dit nie dat Calvyn Hom soms as Outeur van die Skrif, en dan veral van die NT, aandui nie. Soms word God as die Outeur genoem. Tog is dit die eintlike, die eie-aardigheid van die Heilige Gees dat Hy as die Gees van die Vader en die Seun, die Outeur van die Skrif is. Uit die reeds aangehaalde uitsprake van Calvyn is dit duidelik genoeg. Dit is net nodig om weer te onderstreep dat die inspirasie van die Gees nie net om die inhoud gaan nie, maar ook om die betroubare weergawe van die inhoud. Hiertoe het die Gees die bybelse getuies selfs in hulle woordkeuse gelei ${ }^{29}$. Vorm en inhoud kan dus volgens Calvyn nie so gemaklik onderskei (of selfs geskei) word as wat die liberale teoloë sedert Semmler geglo het nie.

Maar wat nou van die „Outeur" en die „outeurs”? Kan ons hier praat van die Autor Primarius en die autores secondarii? Hierdie gebruiklike onderskeiding ontbreek nie net by Calvyn nie, maar word deur hom ontken. Die woord "Skrif”, sê hy, beteken dat Moses nie die outeur van die wet was nie, maar dat hy slegs skrywer 
of griffier onder die mond van God was. Net soos 'n sekretaris wat hom beveel word, sal neerskryf, net so word hier met nadruk beklemtoon dat Moses geskryf het wat hy van God ontvang het, en nie dit wat hy self versin het nie ${ }^{30}$. Calvyn hou dus saam met die kerkvaders vol: God die Heilige Gees is die Outeur van die Bybel. Hy is nie die "Primêre Outeur" nie - hy is die enigste Outeur.

Korrelaat met die onderskeiding van 'n primêre en 'n sekondêre "outeur" gaan die openbaring van die Goddelike en die menslike „faktor" in die openbaring en teboekstelling ${ }^{31}$. As daar één ding is wat 'n reeks ellende in die Geref. dogmatiek gesaai het, dan is dit hierdie stuk skolastiek. Dit lyk (skynbaar) maklik genoeg om te onderskei tussen die Goddelike en die menslike "faktor", maar die eintlike probleem word eers akuut as jy die grens moet trek tussen die twee "faktore" en vasstel wat wár behoort. Hierdie teorie rus op twee (onuitgesproke) veronderstellinge. Die eerste is dat die Goddelike en menslike „faktore" as konkurrente beskou word. Dit sien ons in die feit dat, hoe meer die historiese navorsing die "menslikheid" van die Bybel aan die lig gebring het, hoe groter het die bedreiging vir die gesag van die Skrif geword. Die tweede veronderstelling is ' $\mathrm{n}$ rassionalistiese geloof in die inherente krag en vermoë van die (al is dit selfs ,verligte") menslike rede om die geheimenis van Gods openbaring te kan deurvors en verklaarbaar te maak. Dit was die verdienste van Cramer dat hy gewys het op die fatale konsekwensies wat volg wanneer die geloof in die inspirasie van die Skrif moet rus op 'n rasionele teorie oor hoe die inspirasie presies plaasgevind het.

Gelukkig het Calvyn nie met „faktore" gewerk nie! Hy het gebuig voor die geheim van die gesag van die Skrif sonder om dit te probeer verklaar. Hy maak hom nie druk oor die inspirasie nie. Vir hom was die Skrif eenvoudig die boek met die Woord van apostels en profete waardeur God spreek ${ }^{32}$.

Hy bely ten volle die Goddelike ingewing van die Skrif. Aan die anderkant erken hy voluit die menslikheid, tydgebondenheid, agtergrond, gawes, sielkundige disposisie ens. van die ,skrywers". Die Gees het eenvoudig die ,griffiers" in hulle konkrete historisiteit só in beslag geneem en hul spreke só regeer dat hulle die ontvange Woord gehoorsaam en getrou weergegee het, vry van enige eie toevoeging of weglating ${ }^{33}$. Daarom die eienaardige feit dat die Goddelike en die menslike by Calvyn as 't ware uitruilbaar is. Dit blyk nie alleen daaruit dat Calvyn in een sin kan sê dat die Gees dit gespreek het, terwyl hy in 'n volgende sin die uitspraak aan Lukas (of Johannes, ens.) wyt nie, maar ook uit die opmerklike toedrag van sake dat Calvyn een en dieselfde uitspraak aan die Heilige Gees en 'n bepaalle mens toeskryf ${ }^{34}$.

Hierdie uitsprake staan dikwels in die konteks van die aanpassing: die Heilige Gees het Hom aangepas aan die bevattingsvermoë van diegene tot wie Hy spreek. Maar dieselfde uitdrukking word van die bybelskrywers gebruik! Hierdie aanpassing is geen aanpassing aan die primitiewe voorstellingswêreld van die oudheid nie maar 'n ,aanpassing aan ons swakheid", aan die hulpeloosheid 
van die mens teenoor die openbaring as sodanig. Die Gees, kan ons sê, lê beslag op mense en gebruik hulle nie net ten spyte van hulle beperktheid nie (Pilatus, Bileam!) maar ook omrede van hulle beperktheid om die Woord van God vir ons bevatlik te maak. Hierdie „uitruilbaarheid" van „Outeur" en bybelskrywers bring Krusche tot die konklusie: Gods Woord en die mensewoord is identies - al is dit geen direkte identiteit nie maar 'n gebroke een ${ }^{35}$.

Calvyn praat hier wel van ,twee stemme", en van 'n onderskeiding (distinctio), maar betrek dit nie op die inhoud van die Skrif nie maar op die ontstaanstyd: die onderskeiding is nodig sodat ons kan begryp wanneer (quando) die Here beveel het en wanneer die profete en bedienaars die bevele gevolg het ${ }^{36}$. By hierdie aanpassing van die Gees aan ons swakheid sou ons kan praat van 'n pneumatologiese analogie aan die kenosis van die Seun in die vleeswording.

Die onderskeiding van die Goddelike en die menslike faktor funksioneer ook nog op 'n ander vlak, nl. dié van die geskiedenis van die teboekstelling van die Skrif en die latere kopiëring daarvan. Hier is die opvatting dan dat alles onder die kontrole van die Goddelike faktor gestaan het totdat die Woord in Skrif vasgelê is. Daarna, d.w.s. by die vasstelling van die kanon en die oorskryf van die Skrif, funksioneer eintlik net die menslike faktor. Die resultaat hiervan is dat ons 'n foutlose, verbaal-geinspireerde outograaf het, maar ook ander kopieë daarvan, wat vanweë die menslike faktor wel foute het. Calvyn het hom gevolglik net met tekskritiek besig gehou ${ }^{37}$.

Hierdie argument bied maar 'n skrale troos want ons het die outograaf nie meer nie. Wat ons het, is slegs 'n Bybel met menslike foute! Ek kan my moeilik voorstel dat dit vir Calvyn bo alles gegaan het om die volmaaktheid van 'n verlore outograaf en nie om die vastheid, betroubaarheid en nabyheid van die Woord wat ons het nie. Bowendien het Calvyn nie angsvallig probeer om die eerste drie Evangelies te harmoniëer nie (soos Osiander), en die gedagte dat hy hom net met „tekskritiek" besig gehou het, is moeilik vol te hou. Jy moet die begrip baie wyd rek om alles in te sluit wat Calvyn gedoen het. So het Matt. 27:9 geen variasies in die tekslesings nie en Calvyn kies dus nie hier vir die beste lesing nie. Op grond van die gegewens in die OT kan hy eenvoudig sê dat hy nie weet hoe die naam van Jeremia hier ingesluip (obrepserit) het nie en hom nie daaroor gaan moeg maak nie. Die saak toon duidelik dat dit Sagaria moet wees.

'n Mens kan hierdie ,insluip" nog tekskrities interpreter as jy 'n ruim gemoed het. By Hand. 7:16 word dit egter onmoontlik as Calvyn van Lukas sê: „But when he goes on to say that they were buried in the sepulchre which Abraham had bought from the sons of Hamor, it is obvious that an error has been made in the name of Abraham" 38 .

Hier word die Skrif eenvoudig met homself vergelyk. As dit vir Calvyn om 'n verbaal geinspireerde, foutlose teks gegaan het, moes hy minstens in hierdie gevalle probeer harmoniëer het. 


\section{DIE ERKENNING VAN DIE SKRIFGESAG}

Die Skrif is vir Calvyn sonder twyfel autopistos, geloofwaardig in homself omdat dit getuig dat dit van God kom. Die gesag word nie deur die kerk aan die Skrif verleen nie (Rome) maar lê objektief in die Skrif self ${ }^{39}$. Die gesag van die Skrif kan ook nie deur rasionele argumente begrond word nie. Hierdie argumente dien nie om die gesag van die Skrif te bewys nie maar om die monde van die ongelowiges te snoer. Die Skrif het geen buite-instansie (kerklike gesag, menslike rede) nodig om sy gesag te bewys nie ${ }^{40}$.

Maar as die Skrif dan autopiston is, self getuig dat dit God se Woord is wat deur profete en apostels gespreek is, hoe kom dit dan dat hierdie aksioma nie deur alle mense erken en geglo word nie? Hierop antwoord Calvyn dat die mens vanweë die sonde doof en blind is. Hy kan hierdie aksioma nie sien nie - daarvoor moet die Gees sy oë verlig om te sien en sy ore deurboor om God se stem te hoor. Só bind die Gees ons alleen aan die Skrif. Dit kom duidelik uit in Calvyn se houding teenoor die Wederdopers. Wanneer lg. hulle op allerlei Geestesopenbaringe beroep, antwoord Calvyn dat die Gees aan die Woord gemeet moet word ${ }^{41}$.

Ek wil hierdie moeilike probleem van drie kante af net kortliks aanraak: (a) die sekerheid van die autopistie; (b) wat die inwendige getuienis van die Heilige Gees behels; (c) of ons nie hier met 'n bose sirkel t.o.v. Woord en Gees te doen het nie.

(a) Karl Heim het in 'n buitengewoon interessante studie oor die sekerheidsbegronding aangetoon hoe Luther die twee alternatiewe van die Middeleeue in 'n briljante sintese saamgevoeg het ${ }^{42}$.

In die Middeleeue was daar twee opvattinge oor die begronding van teologiese sekerheid - eerstens die meer realistiese rigting van die ou Fransiskanerskool, w.o. Alexander van Hales en Bonaventura, wat die tradisie van Augustinus in hoofsaak voortgesit het, en tweedens die rigting wat meer nominalisties georiënteer was en in Aquino sy hoogtepunt bereik. Eg. het die aksiomatiese en lg. die outoritatiewe opvatting verteenwoordig. Gedurende die Middeleeue is daar in hierdie twee alternatiewe bly vassteek: of die hooggste waarheid is selfevident en derhalwe as die absoluut onbepaalde unum verum bonum a priori kenbaar, terwyl die Skrif slegs 'n simboliese voor. stelling en 'n materiële handleiding is tot hierdie ",hoogste Goed" wat bokant die historiese Skrifinhoud lê, of die hoogste waarheid het die kontingente inhoud van die Skrif, wat letterlik, woordeliks verstaan moet word. Dan is die waarheid nie selfevident nie, maar kan alleen deur 'n gesagsinstansie vasgestel en gewaarborg word. Hierdie dilemma van of aksiomatiese sekerheid of gesagsgewisheid vind dan in die sintese van die Reformasie uitdrukking in die paradoksale formule van de autopistie van die Skrif: Die Skrif getuig van homself en het dus die evidensie van 'n aksioma - en tog is sy inhoud nie aksiomaties nie maar kontingent. D.w.s. die Skrif het ten spyte van sy selfevidensie nie die dwingende oortuigingskrag van 'n aksioma wat alle denkendes onmiddellik aanvaar nie. P. Althans stel dit mooi: dit gaan om 'n ,,axiomatische Gewissheit des Kontingenten" - iets wat alle logiese reëls laat versplinter. 
Calvyn staan voluit in hierdie tradisie van die Reformasie: Die Skrif is autopiston, is selfevident, maar die aksiomatiese krag van die Skrif kom eers ter sprake deur die getuienis van iemand anders - van dieselfde Gees wat die Skrif ingegee het en van die Skrif getuig.

(b) Die vraag is nou: is hierdie testimonium Spiritus sancti 'n aparte, direkte openbaring wat as nuwe inhoud in my bewussyn gelê word, sodat ek dan die Bybel neem en sê: nou weet ek dit is die Woord van God? Met ander woorde is die inwendige getuienis van die Gees die grond van ons geloof dat die Skrif autopiston is, soos H. H. Kuiper dit pertinent gestel het, of is dit net die middel waardeur ons tot dié wete kom? ${ }^{43}$ Hierdie saak was al aan die orde in die polemiek van A. Kuyper en Haitjema. Kuyper praat van 'n „getuigenis dat rechtstreeks van den Heilige Geest, als de auteur der Schrift, tot ons persoonlik ik uitging (my kursivering) ${ }^{44}$.

Kuyper was hierin geen goeie leerling van Calvyn nie. Nêrens in die werk van Calvyn word gesuggereer dat die Gees regstreeks in die mens se bewussyn 'n aparte inhoud openbaar nie. Deur die getuienis van die Gees word die selfevidensie van die Skrif vir die gelowige 'n aksiomatiese sekerheid. Dat die Skrif Gods Woord is word deur die getuienis van die Gees ,'n oortuiging wat geen begronding nodig het nie", tot 'n wete „wat sy grond in homself dra" 45 . Die getuienis van die Gees is dus nie die grond van ons wete dat die Skrif Gods Woord is nie - dit is veeleer die evidente Skrif self - maar dis die middel of die bewerkende oorsaak van daardie sekerheid ${ }^{40}$. Die Gees laat ons slegs sy beeld herken wat Hy op die Skrif afgedruk het.

Die inwendige getuienis van die Gees is geen formele getuienis aangaande die feit dat die Skrif Gods Woord is nie. Die Gees wat ons deur die Woord aan die Woord bind verseël terselfdertyd die beloftes van die Woord aan ons harte. Calvyn skei ook hiér nie tussen vorm en inhoud nie. Ons kan sê dat hy nie eers onderskei nie. Skrifgetuienis en heilsgetuienis is nie twee dinge nie maar één. Dit sien ons daarin dat Calvyn sê dat net die uitverkorenes werklik die stem van God in die Skrif hoor en sy beloftes in hulle hart verseël kry. Tereg formuleer Krusche: „Der Geist ist keine zweite Autorität neben der Schrift, sondern seine Autorität ist die der Schrift, deren Autor er ist; er offenbart nicht neue Inhalte, sondern macht des Inhalts der Schrift als Gottes Wort gewiss" ${ }^{47}$.

Só word die gelowiges gebring, nie tot 'n formele erkenning dat die Skrif van God kom nie, maar tot die materiële erkenning dat hierdie Woord van God vir hulle geld en dat al sy beloftes in Christus ja en amen is ${ }^{48}$.

(c) Hiermee het ons eintlik al antwoord gegee op die vraag of ons nie hier met 'n bose sirkel te doen het nie. Heim sien dit as 'n sirkelredenering: vir die Goddelike gesag van die Skrif wys Calvyn op die inwendige getuienis van die Gees, terwyl hy later vir die vraag na die waarheid van die Geestesgtuienis weer terugwys op die Skrif, wie se waarheid egter eers deur die getuienis van die Gees bevestig moet word.

Indien Calvyn die inwendige getuienis van die Gees as 'n 
aparte getuienis buite die Woord om, direk in ons bewussyn gesien het, sou die kritiek van Heim inderdaad opgegaan het. Dit is juis die fout van die Wederdopers dat hulle Woord en Gees van mekaar losmaak. Van hulle praat Calvyn in Inst. 1, 9. Maar dan het hy nie meer die inwendige getuienis van die Gees waarvan hy in Inst. $1,7-8$ gepraat het in die oog nie, maar juis die Geestesopenbaringe waarop die Wederdopers hulle beroep. Die vraag is in Inst. 1, 9 nie of ons die inwendige getuiennis van die Gees kan vertrou nie maar hoe ons moet staan teenoor die werkinge van die Gees, wat, los van die Woord, nuwe openbaringe gee. Die inwendige getuienis gaan buite ons bewussyn om, is deur introspeksie nie bereikbaar nie, maar bind ons juis die aan die inhoud, die materie van die Woord. Dit is die beslissende onderskeid tussen die inwendige getuienis van die Gees en die „openbaringe” van die Wederdopers: eg. is nie materieel nie maar bind aan die materie van die Woord, terwyl lg. nuwe materiële inhoude buite die Woord om aan die mense medeel. Calvyn het skerp gesien dat die Wederdopers daarmee die Woord degradeer. In die degradering van die Woord kom Rome en die Anabaptiste, die regter- en die linkervleuel ooreen.

\section{'N SPIEEL VIR ONS}

So 'n paar ontsporinge van Calvyn se standpunt het uit wat hierbo gesê is, duidelik geword. Die vraag is nou of ons nog staan by die erfenis van die Reformasie soos ons pretendeer om te doen. Of het ons in werklikheid gesak na 'n formalistiese Skrifbeskouing wat rasioneel in teorieë verklaar moet word? Verduister ons nie die Skrif se gesag deur dit te hul in "amptelike belydenisskrifte" wat wesenlik funksioneer as 'n kerklike gesag nie? Doen ons dit nie soms - heel welmenend en onbedoeld - in ons kategese en teologiese opleiding nie? Funksioneer die Skrif self nie dikwels as 'n formele gesagsinstansie waarop ons ons beroep om ons eie optrede, ons kerkwees, ons politieke beleid te regverdig nie? Verbaas dit ons dan as die pendulum van Rome na Münster swaai, van regs na links in 'n soeke na 'n ruspunt? Laat ons dit van die Reformasie leer: die eerbied vir die Skrif, die nederige gehoorsaamheid aan die stem van God - om dit te hoor en te gehoorsaam, selfs teen ons eie smaak in - dit is ons reformatoriese erfenis wat ons die lewende God laat dank, en wat ons bewaar vir outoritisme én geesdrywery; maar 6ók vir die liberale rasionalisme wat die historiese tot norm verhef, wat die werk van God in die openbaring en teboekstelling van die Skrif probeer relativeer, verpsigologiseer en verkontekstualiseer. Met hierdie rasionele kunsgrepe kan jy die Skrif nie van sy krag beroof nie, en ewe min sy gesag bewys. Want die Gees en die Woord transsendeer die tyd én die menslike rede, is nie gebonde nie en werk onnaspeurlik soos die wind. 


\section{VERWY SINGS}

1 J. A. Loader: "The use of the Bible In Conventional South African Theology" in Scripture and the Use of Scripture, Unisa, 1979, p. 6.

2 Vgl. R H. Bremmer: "De Heilige Schrift als Woord Gods", in In die Skriflig, $\mathrm{nr} 1,1966, \mathrm{p} .12$.

3 Ioannes Calvini Opera Selecta (edit. P. Barth) I, p. 418.

4 Corp. Ref 30, 12: „Coeleste oraculum excidere non potest....'

5 Inst. 1, 7, 1.

6 Inst. 1, 7, 5 .

7 Inst. 2, 8, 58

8 Inst. $4,17,36$.

9 Serm. 21 (Deut, 4); Corp. Ref. 54, 131.

10 D. J. de Groot: Calvijns Opvatting over de Inspiratie der Heilige Schrift, p. 35

11 Corp Ref. 54, 282: Ainsi donc apprenons que, sur tout Dieu nous recommande l'honneur et l'authorité de sa parolle. Comme s'il disoit, que tout ce qui est contenu en l'Escriture sainte, il faut que nous le recevions en toute humelité, nous rendans dociles à se qui est là contenu. Voire, et combien que cela soit contraire à nostre sens, et que nous voudrions que Dieu eust parlé à nostre guise: toutesfois que nous luy facions cest honneur, de captiver tous nos sens, et dire, Seigneur, nous sommes tes dirciples, nous recevons paisiblement ce qu'il t'a pleu nous enseigner, sachans que cela set pour nostre profit et salut. Sans exception donc, que tout ce qui est contenu en l'Escriture sainte soit receu avec reverence...."

12 Inst. 1, 9, 2.

13 Id 1, 6, 1. $\mathrm{Vgl}$ ook Inst 4, 8, 6: ,But when God determined to give a more illustrious form to the Church, he was pleased to commit and consign his word to writing, that the priests might there seek what they were to teach the people and every doctrine delivered be brought to it as a test (Mal. $2: 7)$,"

14 Inst. 1, 6, 2.

15 Corp. Ref. 70, 510 Dit is die moeite werd om op te merk dat De Groot, wat oortuig is dat Calvyn die grafiese inspirasie geleer het, soms 'n bietjie vry met die oorspronklike teks omgaan. Die laaste sin in vrye vertaling lui (sonder aanhalings) dat Hosea dit wat hy dikwels moes repeteer ,in dit boek (heeft) samengevat, opdat het zou dienen als een volkomen verzegeling van hetgeen hij mondeling heeft verkondigd" a.w., p. 78). Calvyn het dit darem effe anders gese: "Quod. . nunc ad finem libri sui posuit ut sit quasi legitima obsignatio totius doctrinae(!)".

16 Inst. 4, 8, 6 en 7.

17 J. A. Cramer: De Heilige Schrift bij Calvijn, Utrecht, 1926.

18 Waar die uitdrukkinge by Calvyn voorkom, word breedvoerig aanggeee deur Krusche: Das Wirken des Heiligen Geistes nach Calvin, p. 162-163. Vgl. ook: L. F. Schulze: „Die Skrifbeskouing van die Reformatore”, in In die Skriflig, nr. 13, p. 30-34.

19 Gegewens by De Groot, a w p. 135 v.

20 Corp. Ref. 70, 493 (Kommentaar op Hosea $13: 14$ ).

21 Il., 77, 339 (Komm. 1 Kor. $2: 9$ ).

22 Inst. 1, 8, 2 .

2: Vgl. ook Bileam Corp. Ref. 56, 82-83: Voila un faux prophete qui parle d'un style aussi excellent qu'il est possible de la verité immuable de Dieu. 
24 Quia primum aeterna sit Dei sapientia et voluntas, deinde expressa consilii eius effigies. (Corp. Ref 75, 1).

25 Ergo filium ab intimis secretis patri fuisse docet, ut sciamus in evangelio nos habere quasi apertum Dei pectus.

26 A.w., p. 88.

27 Inst. $4,8,5$.

28 Id. 4, 8, 7.

29 Vgl Krushe, a.w., p. 173.

30 Serm. Deut. 31:22-30: notons, que ce mot .d'Escriture" emporte que Moyse n'a point esté autheur de la Loy ne du Cantique, mais qu'il esté seulement escrivain ou greffier sous la bouche de Dieu.

31 Vgl. die laaste drie hoofstukke van De Groot se werk. Vgl. ook Bremmer, a.a., p. 17-21.

32 So merk Bremmer tereg op, a.a. p. 18

33 So se W. Krushe tereg, a.w. p. 1755.

34 Bv. in 'n preek oor Job 10:7 v: Et comment? le S. Esprit n'avoit-il point des choses plus propres à dire?.... Or ce n'est point sans cause que Job a ainsi parlé. Vgl ook Comm. Gen. $7: 13$

35 Krusche, a.w. p. 175.

36 Comm. Jes. 40:6. Tametsi vero prophetarum vox sit etiam Dei, cuius organa sunt, (nec enim ex se ipsis loquuntur) tamen haec distinctio necessaria est, ut intelligamus quando iubeat Dominus, quando prophetae et ministri iussa exsequantur. Et concinna est inter duas voces comparatio, ut dicomus non minus reverenter excipere quod afferunt prophetea, quam si tonaret Deu ipe e coelo....

37 Dis die standpunt van De Groot en ook van Murray: John Calvin on Scripture and Divine Sovereignty, Grand Rapids, 1960. Vgl. C. F. C. Coetzee: Calvyn en die Skrif, 2de druk, p. 8.

38 Calvin's Commentaries (ed. D. W. Torrance and T. F. Torrance) op Hand $7: 16$. Vgl, Krusche, a.w. p. 179-184 oor Calvyn se "Skrifkritiese" opmerkings. ,

$39 \mathrm{Vgl}$. Inst. $1,7,4$ en noot 10 . Ook Inst. $1,7,1-3$

40 Inst. 1, 8, 1: Si nous n'avons ceste cestitude plus haute et plus ferme que tout iugement humain en vain l'authorité de l'Escriture sera approuvée par argumens, en vain elle sera establie par le consentment de l'Eglise ou confermee par autres aides - teks volgens die uitgawe van J. D. Benoit. Vgl. Inst 1, 7, 4: Néantmoins ceux qui veulent et s'efforcent de maintenir la foy de l'Escriture par disputes pervertissent l'ordre.

41 Inst. 1, 9,

42 Karl Heim: Das Gewissheitsproblem in der systematische Theologie bis zur Schleiermacher, 1911.

$43 \mathrm{Vgl}$. oor hierdie verskil van ponie, Bremmer, a a. p. 22-26.

44 A. Kuyper: Encyclopedie, II, p. 511.

45 Inst. 1, 7, 5.

46 So merk Krusche tereg op. Bavinck en Greijdanus maak ook dié onderskeiding. Berkouwer gaan breedvoerig daarop in: "Ons glo die Skrif niet om maar door het getuigenis van de Geest" (De H. Schrift, I, p. 60).

47 Krusche, a.w. p. 216

48 Comm. Eph. 1:13: vera igitur persuasio, quam de verbo Dei, de salute sua, de tota religiome habent fideles: non est ex humanis aut philosophicis rationibus, sed ex spiritus obsignatione - sitaat by Krusche, a.w. p. 217. 